\title{
Differential and Mutually Exclusive Expression of CD95 and CD95 Ligand in Epithelia of Normal Pancreas and Chronic Pancreatitis
}

\author{
Cornelia Hasel, Bettina Rau, Sven Perner, Jörn Sträter, and Peter Möller \\ Departments of Pathology (CH, SP, JS, PM) and General Surgery (BR), University of Ulm, Ulm, Germany
}

\begin{abstract}
SUMMARY: Acinar regression in chronic pancreatitis may be due to immune attack in parenchymal areas neoexpressing HLA-DR molecules. CD4 ${ }^{+}$Th1 cytotoxic T cells induce apoptosis of their targets via oligomerizing CD95 (APO-1/Fas) death receptors on target cells by their CD95 ligand (CD95L). We determined the expression of CD95 and CD95L in epithelia of normal and chronically inflamed pancreatic tissues. We applied RT-PCR and Western blotting for CD95L expression profiles, serial frozen section immunohistochemistry to detect CD95, CD95L, and HLA-DR molecules, CD3, CD4, CD11c, and S-100 protein (S100p). Normal pancreases and chronic pancreatitis contain CD95L message and protein. Immunohistochemistry revealed a mutually exclusive expression of CD95 and CD95L. Physiologically, acini were CD95 ${ }^{-} / \mathrm{CD} 5 \mathrm{~L}^{+}$, ducts were $\mathrm{CD}^{-} 5^{-} \mathrm{CD} \mathrm{CL}^{-}$, and islets were $\mathrm{CD}^{-} 5^{-} / \mathrm{CD} 5 \mathrm{~L}^{+}$. In areas of lymphohistiocytic infiltration, mainly consisting of $\mathrm{CD}^{+} \mathrm{CD} 4^{+} \mathrm{T}$ cells and $\mathrm{CD} 11 \mathrm{c}^{+}, \mathrm{CD} 4^{+/-}$, S100 $\mathrm{p}^{+}$interstitial dendritic cells, and in areas of initial fibrosis, acini and ducts were HLA-DR ${ }^{+}$, acini $\mathrm{CD}^{+} 5^{+} / \mathrm{CD} \mathrm{CL}^{-}$, and ducts

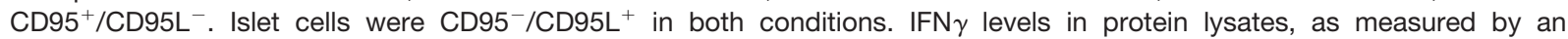
immunoassay, were significantly higher in chronic pancreatitis than in normal pancreas $(p<0.0003)$. In vitro, IFN $\gamma$ downmodulated CD95L message and protein in ASPC1 and BxPc3 pancreatic carcinoma cells. In conclusion, pancreatic epithelia differentially express CD95 and CD95L in a mutually exclusive manner. In chronic pancreatitis the $\mathrm{CD}^{-} 5^{-} \mathrm{CD} 95 \mathrm{~L}^{+}$status is conserved in islet cells even in the vicinity of lymphohistiocytic infiltrates, whereas it is lost in acini coexpressing HLA-DR. As a potential consequence, and possibly triggered by local release of IFN $\gamma, \mathrm{CD}^{+} \mathrm{Th} 1$ cells may cognately interact with and successfully attack exocrine cells by triggering CD95 on their target without being killed by epithelial, CD95L-mediated, counterattack. (Lab Invest 2001, 81:317-326).
\end{abstract}

$C$ hronic pancreatitis is characterized by a progressive loss and fibrosis of exocrine parenchyma whereas the endocrine part of the organ remains structurally intact for a prolonged period of time (Bockman, 1997; Klöppel and Maillet, 1993; Sarles, 1991). The disease is often accompanied by duct ectasia and might be initiated by ductal obstruction or distortion (Klöppel and Maillet, 1993). Furthermore, foci of lymphohistiocytic infiltrates are commonly found and are also associated with regressing parenchyma (Bockman, 1997). These infiltrates were shown to contain activated cytotoxic $T$ cells (Hunger et al, 1997), suggesting a role of the immune system in the pathogenesis of acinar atrophy and local scarring. Induction of HLA-DR molecules was observed in parenchymal areas affected by chronic pancreatitis $(\mathrm{Be}-$ dossa et al, 1990; Jalleh et al, 1993) and transcripts for MCP-1 chemokine have been detected in areas of early stage of chronic pancreatitis (Saurer et al, 2000). Local expression of $\mathrm{T}$ cell tropic chemokines may recruit $T$ cells, the CD4 subset of which then may

Received October 11, 2000.

Supported by a grant by the Deutsche Forschungsgemeinschaft (SFB 518) A6) to BR and PM.

Address reprint requests to: Dr. Peter Möller, Department of Pathology, Ulm University, Albert-Einstein Allee 11, D-89089 Ulm, Germany. E-mail:peter.moeller@medizin.uni-ulm.de cognately interact with HLA-DR neoexpressing epithelial cells. Like $\mathrm{CD}^{+} \mathrm{T}$ cells, $\mathrm{CD} 4^{+} \mathrm{Th} 1$ cells have been shown to exert a cytotoxic function via apoptosis induction by binding the CD95 receptor of target cells (Ju et al, 1994).

CD95 (APO-1/Fas) is a 48-kDa type I membrane glycoprotein and a member of the tumor necrosis factor (TNF) receptor family. On oligomerization of CD95 by antibody or trimerization by its natural ligand, CD95L, it confers an apoptotic signal to apoptosissensitive cells (Peter and Krammer, 1998). CD95L is a 40-kDa type II membrane protein that belongs to the TNF family of cytokines (Takahashi et al, 1994). Like other members of this family, CD95L exists in a membrane-bound and soluble form (Dhein et al, 1995). CD95L is expressed on activated $T$ cells (Tanaka et al, 1995), preferentially on $\mathrm{CD}^{+} \mathrm{Th} 1$ cells (Ju et al, 1994; Lynch et al, 1995), and in plasma cells (Sträter et al, 1999). Outside the immune system, we detected CD95L transcripts in Paneth cells (Möller et al, 1996). By immunohistochemistry using a polyclonal rabbit antiserum, Lee et al (1999) detected CD95L in a limited number of other epithelial cell types, eg, trophoblast cells, pituitary anterior lobe cells, and gastric parietal cells. However, gastric parietal cells do not express CD95L transcripts (Möller et al, 1996). Although the concept of immunoprivileged sites, defined as such by CD95L expression in resident cells 
potentially counterattacking intruder $\mathrm{T}$ cells, is currently very attractive, the CD95L expression profile of many normal human tissues, pancreas included, is not yet convincingly determined. By contrast, more is known about CD95 expression in normal human tissues (Leithäuser et al, 1993). Unlike many other types of epithelial cells, ductal and endocrine epithelia of normal pancreas are constitutively CD95 ${ }^{-}$. Likewise, the majority of acinar cells were found to be CD95 ${ }^{-}$, whereas those few expressing CD95 seemed to be induced by local inflammatory infiltrates, as observed in chronic prostatitis and chronic sialadenitis (Leithäuser et al, 1993).

This study was undertaken to exactly determine the expression of CD95 and CD95L in normal pancreatic epithelia and to analyze the CD95/CD95L status of pancreas epithelia in chronic pancreatitis. Unexpectedly, we found by immunohistochemistry that all pancreas islet and acinar cells constitutively express CD95L. In chronic pancreatitis we observed striking parallels in the induction of CD95 and HLA-DR molecules in exocrine cells close to lymphohistiocytic infiltrates. This local neoexpression of CD95 and HLA-DR was associated with a loss of CD95L in the same parenchymal microareas. By contrast, even in the vicinity of lymphohistiocytic infiltrates, islet cells remained CD95 ${ }^{-}$, HLA-DR ${ }^{-}$, and CD95L ${ }^{+}$.

\section{Results}

\section{CD95L Expression in Normal Pancreas and Chronic Pancreatitis}

Normal pancreases and representative tissue specimens of seven cases of chronic pancreatitis were successfully subjected to mRNA and protein extraction. Referred to the amount of message of the housekeeping gene SP1, RT-PCR revealed CD95L transcripts in both normal pancreas and pancreatitis (Fig. 1). In our series, the five normal pancreases expressed CD95L transcripts at a higher level than five of seven inflamed pancreases (Fig. 1, A, B, D, and E). The pancreatic cell line AsPc1, known to express CD95L transcripts (Bernstorff et al, 1999; Ungefroren et al, 1998), was used as the positive control. The colon carcinoma cell line HT29 chosen as the negative control (O'Connell et al, 1996) did not reveal detectable amounts of CD95L message. In parallel, both normal and chronically inflamed pancreatic tissues contained CD95L protein as detected by Western blot analysis (Fig. 1, C and F). Corresponding to the mRNA data, AsPC1 but not HT29 cells expressed CD95L protein. There was, however, no stringent correlation between the amount of transcripts and protein in the tissue extracts. Thus, normal and chronically inflamed pancreatic tissues express CD95L and, at least at the mRNA level, CD95L might be down-regulated in chronic pancreatitis.

\section{Immunodetection of CD95L In Situ}

Using CD95L monoclonal antibody G247-4 to frozen tissue sections, CD95L protein was detected in pan- creatic epithelia. In normal pancreas, CD95L was present in every acinar cell in a supranuclear cytoplasmic location. Duct epithelia were CD95L- (Fig. 2). Islet epithelia were CD95 $\mathrm{L}^{+}$in a dust-like microgranular cytoplasmic fashion (Figs. 2 and 3). No membraneconfined immunostaining was detected. Endothelial cells were $\mathrm{CD} 5 \mathrm{~L}^{-}$. In chronic pancreatitis, acinar cells were mostly $\mathrm{CD} 5 \mathrm{~L}^{+}$. However, scattered groups of acini were found to be $\mathrm{CD} 5 \mathrm{~L}^{-}$. These $\mathrm{CD} 5 \mathrm{~L}^{-}$acini were involved in cellular interstitial infiltration or adjacent to mild interstitial fibrosis (Fig. 3). Islet cells, by contrast, were found to be CD95L+, even in the vicinity of inflammatory cellular infiltrates and/or fibrosis (Fig. 2). Within the inflammatory infiltrates, immunodetection of CD95L was restricted to plasma cells and scattered cells of lymphohistiocytic infiltrates (Fig. 3). As revealed by serial-section immunohistochemistry, these inflammatory infiltrates were mainly composed of $\mathrm{CD}^{+} \mathrm{CD}^{+}{ }^{+} \mathrm{T}$ cells and $\mathrm{CD} 11 \mathrm{c}^{+}$ S-100 protein ${ }^{+}\left(\mathrm{S}_{100 \mathrm{p}^{+}}\right) \mathrm{CD}^{+/-}$interstitial dendritic cells $(+/-$ denotes admixture of positive and negative cells) (Fig. 3). Collectively, these immunohistologic patterns suggested a down-modulation of CD95L in acinar epithelia associated with local inflammatory infiltration and/or fibrosis.

\section{CD95, CD95L, and HLA-DR Immunoprofiles of Pancreatic Epithelial Components}

The majority of normal glandular epithelia, pancreatic epithelia included, are mainly $\mathrm{CD}^{-} 5^{-}$, but may, on induction, express CD95 in the context of chronic inflammation (Leithäuser et al, 1993). Parenchymal areas involved in chronic pancreatitis have also been shown to neoexpress HLA-DR (Ectors et al, 1997). We thus chose CD95 and HLA-DR as molecular targets to further elucidate the potentially inflammationassociated change in CD95L expression. The resulting immunoprofiles are summarized in Table 1 and paradigmatically depicted in Figures 2 and 3. In microareas with $\mathrm{HLA}_{-} \mathrm{DR}^{+}$lymphohistiocytic infiltrates and in microareas with early fibrosis, the epithelial components of the pancreas showed different patterns of expressional changes. Acini induced for HLA-DR were also $\mathrm{CD}^{+}$and had lost CD95L expression (Fig. 3). In moderately fibrotic microareas, some acini had undergone a morphologic change, recently referred to as tubular acini (Bockman, 1997). Cells of these ectatic, tubular acini showed the same expression pattern as the epithelial cells in globular acini (Fig. 2). The duct epithelium being mixed HLA-DR-positive and -negative in the normal state and in normal areas of inflamed pancreases, turned to entirely $\mathrm{HLA}_{-} \mathrm{DR}^{+}$, especially in ectatic ducts, and also neoexpressed CD95 while remaining CD95L- (Fig. 2). Islet cells in normal pancreas and normal areas of inflamed pancreases were $\mathrm{HLA}^{-D R^{-}}, \mathrm{CD}^{-}$, and $\mathrm{CD}^{-} 5 \mathrm{~L}^{+}$. In striking contrast to acinar and ductal epithelia, islet epithelia did not alter their expressional status; ie, islets adjacent to $\mathrm{HLA}^{-\mathrm{DR}^{+}}$cellular infiltrates and to acini induced for HLA-DR and CD95 still were HLA$\mathrm{DR}^{-}$and $\mathrm{CD}^{-} 5^{-}$and remained $\mathrm{CD}^{-} \mathrm{L}^{+}$. The same 
A

CD95L 344 bp

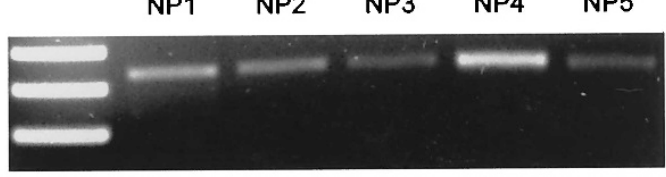

SP1 241 bp

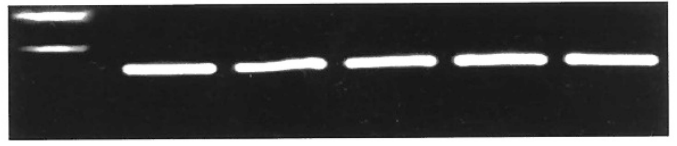

B

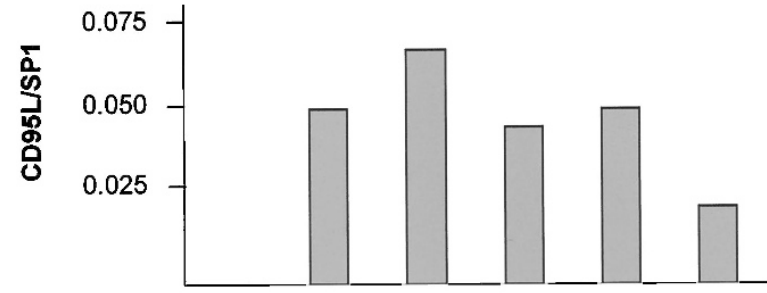

C

CD95L protein $40 \mathrm{kDa}$

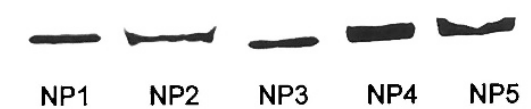

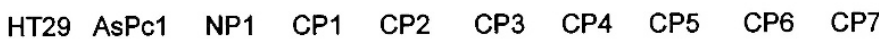

D

CD95L 344 bp

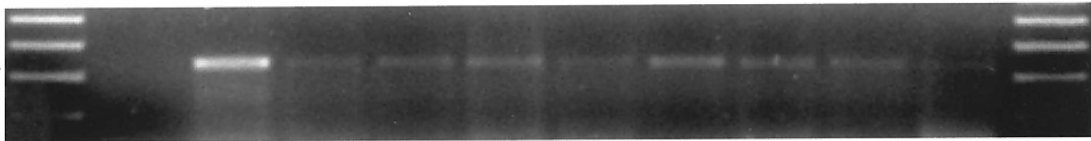

SP1 241 bp

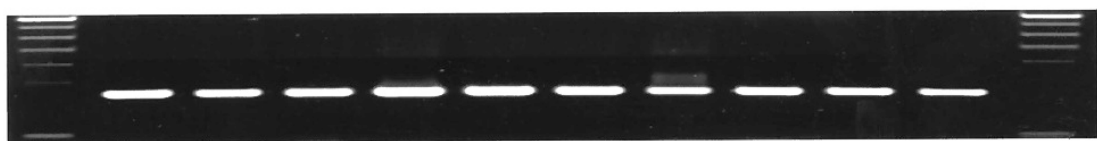

E

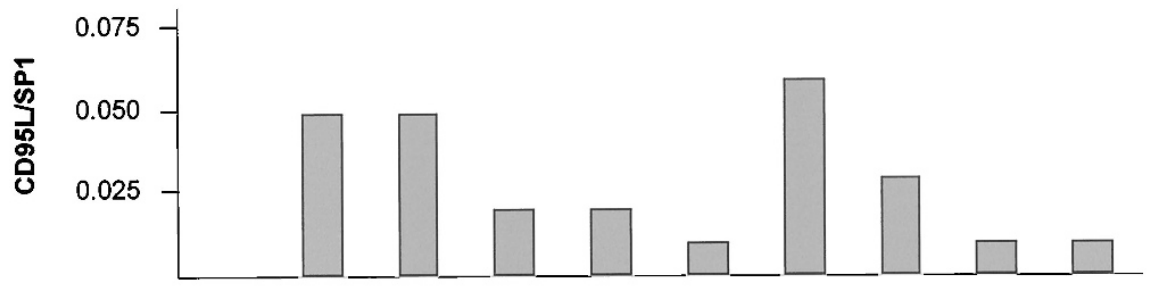

CD95L protein

$40 \mathrm{kDa}$

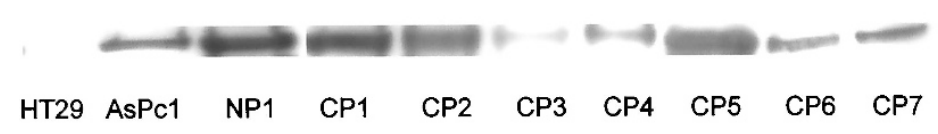

Figure 1.

CD95L transcript and protein expression in five normal pancreases (NP1 to NP5) (A to C) and in seven pancreases with chronic pancreatitis (CP1 to CP7) (D to F) $A$ and D, CD95L and SP1 mRNA detected in an ethidium bromide-stained agarose gel after RT-PCR. Pancreatic carcinoma cell line AsPc1 and colon carcinoma cell line HT29 served as positive and negative control, respectively. NP1, blotted twice, is the standard allowing the direct comparison of intensity of bands. B and E, Ratio profiles of integrated optical densities. C and F, Immunoblots of Western blotted CD95L protein detected by CD95L monoclonal antibody G247-4, visualized by chemiluminescence. NP1 protein, blotted twice, is the standard allowing the direct comparison of intensity of bands.

was true for islets in the vicinity (Fig. 2) of, or surrounded by, fibrosis. In areas with advanced fibrosis, no further immunophenotypic changes were observed. Taken together, these findings suggest that islet cells are nonresponsive to the inflammatory stimuli acting in chronic pancreatitis, which, in acinus cells, leads to loss of CD95L and acquisition of CD95, HLA-DR and causes duct epithelium to up-regulate HLA-DR and induce CD95.

\section{IFN $\gamma$ is Locally Increased in Chronic Pancreatitis}

One key inductor of CD95 is the proinflammatory cytokine IFN $\gamma$ (Möller et al, 1994). In constitutively negative glandular epithelia, IFN $\gamma$ also leads to expression of major histocompatibility complex (MHC) class II products. We therefore determined the content of IFN $\gamma$ in protein lysates of normal and chronically inflamed pancreatic tissue by enzyme immunoassay 

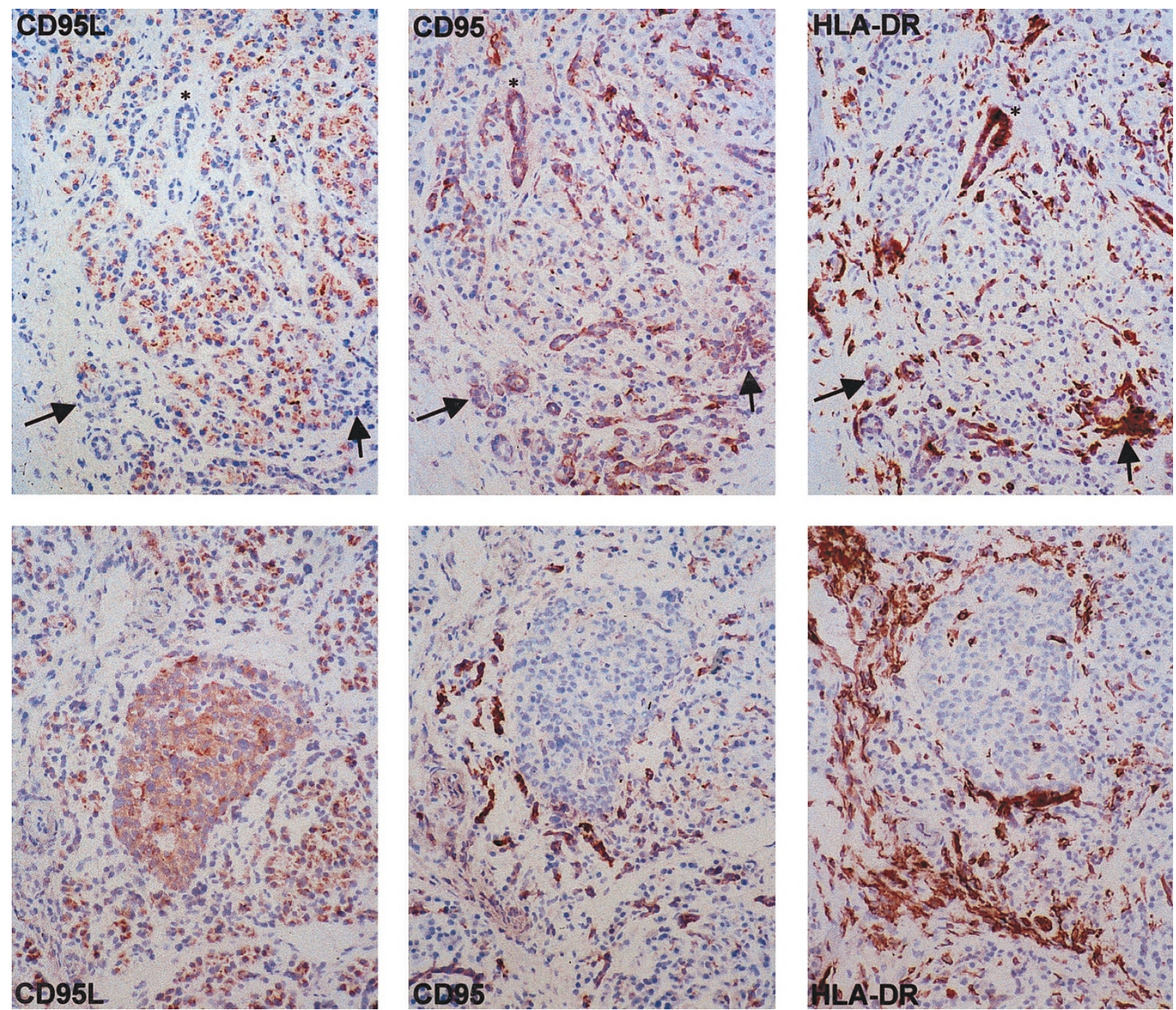

\section{Figure 2.}

Serial frozen section immunohistochemistry on a case of chronic pancreatitis (CP6) showing expression and tissue distribution of CD95L, CD95, and HLA-DR (original magnification, $\times 104)$. Arrows in the upper panels indicate corresponding areas. The right arrow indicates an exocrine parenchymal microarea infiltrated by

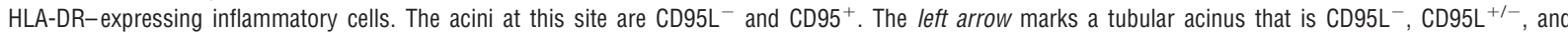
$\mathrm{HLA}-\mathrm{DR}{ }^{+/-}$. The small duct marked by an asterisk is $\mathrm{CD} 5 \mathrm{~L}^{-}, \mathrm{CD}^{+} 5^{+}$, and heavily $\mathrm{HLA}-\mathrm{DR}^{+}$. The lower panels depict an islet surrounded by an inflammatory infiltrate and fibrosis (light interspersed areas). Note that directly adjacent to the islet, there is induction of CD95 in ductular structures and a loss of CD95L in surrounding acinar cells. Endocrine cells of the islet retain their $\mathrm{CD}^{2} 5 \mathrm{~L}^{+}, \mathrm{CD}^{-}, \mathrm{HLA}^{-} \mathrm{RR}^{-}$immunoprofile.

(EIA). As shown in Figure 4A, chronic pancreatitis specimens contained higher amounts of IFN $\gamma$ than normal pancreas. This difference was statistically significant $(p<0.0003)$.

\section{Down-Modulation of CD95L in AsPc1 and BxPc3 by IFN $\gamma$}

These data and the immunophenotypic changes observed in chronic pancreatitis in situ lead to the question whether IFN $\gamma$ can down-modulate CD95L expression in exocrine pancreatic epithelium. As a surrogate, we used the AsPc1 and $\mathrm{BxPc} 3$ pancreatic carcinoma cell lines and stimulated the cells with IFN $\gamma$ for 48 hours. As expected (Moldenhauer et al, 1999) this treatment led to HLA-DR surface expression (data not shown). In accordance with published data (Bernstorff et al, 1999), CD95 was constitutively expressed at the mRNA and protein level. After IFN $\gamma$ treatment there was no significant change in either CD95 mRNA or protein expression. However, CD95 ligationinduced apoptotic rate was increased in both cell lines (data not shown). On IFN $\gamma$ treatment there was a considerable reduction of CD95L mRNA relative to SP1 mRNA (Fig. 4, B and C) that accompanied a decrease in CD95L protein expression (Fig. 4D).

\section{Discussion}

We have shown that normal pancreases and pancreases removed for chronic pancreatitis express CD95L mRNA and also CD95L protein. As revealed by immunohistochemistry, the cells expressing CD95L protein are pancreatic acinar cells and islet cells, whereas duct epithelium is $\mathrm{CD} 5 \mathrm{~L}^{-}$. In the course of chronic pancreatitis, acinar cells in areas of lymphocytic infiltration change to $\mathrm{CD} \mathrm{L}^{-}$, whereas islet cells, even in 

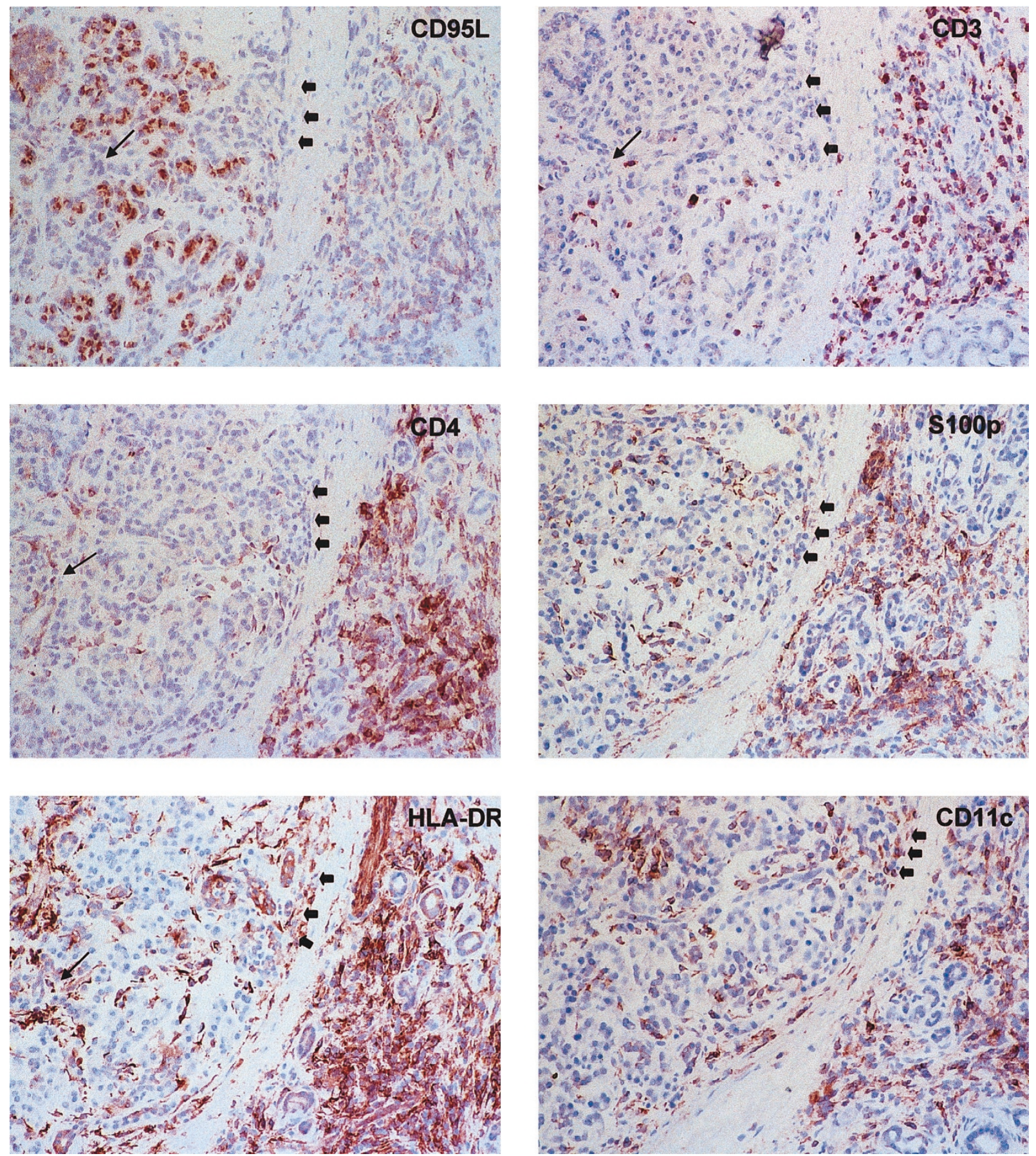

\section{Figure 3.}

Serial frozen section immunohistochemistry on a case of chronic pancreatitis (CP6) showing six different antigens. The micrographs show an informative situation of a sclerotic band in the middle, a parenchymal area affected by a minimal to moderate interstitial fibrosis, and a minimal inflammatory infiltrate on the left, and a heavily inflamed parenchymal area with displacement of ductules and acini by the lymphohistiocytic infiltrate on the right. Note a pancreatic islet at the upper left corner. Long, thin arrows and triple short arrows mark corresponding microareas in different immunostainings (original magnification, $\times 121$ ). CD95L is heavily expressed in exocrine acini of unaffected parenchyma and in islet cells. Arrows mark regions where acini are CD95 $\mathrm{L}^{-}$. The triple arrows mark an exocrine area induced for HLA-DR and infiltrated by scattered CD11 ${ }^{+} / S 100 \mathrm{p}^{+}$dendritic cells. Note that there are no $\mathrm{CD}^{+} / \mathrm{CD}^{+} \mathrm{T}$ lymphocytes at this side. The parenchymal microarea indicated by the single arrow is $\mathrm{CD}_{5} 5 \mathrm{~L}^{-}$, is slightly induced for $\mathrm{HLA}-\mathrm{DR}$, and contains some scattered $\mathrm{CD}^{+} / \mathrm{CD}^{+} \mathrm{T}$ lymphocytes. Accidentally, the corresponding areas are not included in the serial sections stained for CD11c and S100p. At the right side, cells of tubular (ie, ectatic and atrophic) acini are $\mathrm{CD}^{2} 5 \mathrm{~L}^{-}$, HLA-DR and are surrounded by cells of the lymphohistiocytic infiltrate that is heavily HLA-DR ${ }^{+}$and contains scattered CD95L $\mathrm{L}^{+}$cells.

the vicinity of inflammatory infiltration, conserve their high levels of CD95L protein.

These data are at variance with previous reports stating that normal pancreatic tissue is devoid of CD95L transcripts (as tested on a single tissue spec- imen using RT-PCR; Xerri et al, 1997) and CD95L reactivity in immunohistochemistry (Bernstorff et al, 1999; Lee et al, 1999). These negative results may be due to antigen accessibility that is impaired by formalin fixation and/or antibody reactivity (Sträter et al, 
Table 1. Immunoprofile of Pancreatic Epithelia Summarized

\begin{tabular}{|c|c|c|c|}
\hline & $\begin{array}{c}\text { CD95L } \\
\mathrm{n} / \mathrm{cp}\end{array}$ & $\begin{array}{l}\text { CD95 } \\
\text { n/cp }\end{array}$ & $\begin{array}{c}\text { HLA-DR } \\
\text { n/cp }\end{array}$ \\
\hline Acinar cells & $+\rightarrow-$ & $-\rightarrow+$ & $-\rightarrow+$ \\
\hline Cells of tubular acini ${ }^{a}$ & - & + & + \\
\hline Duct epithelium & $-\rightarrow-$ & $-\rightarrow+$ & $+1-\rightarrow+$ \\
\hline Island epithelium & $+\rightarrow+$ & $-\rightarrow-$ & $-\rightarrow-$ \\
\hline
\end{tabular}

$\mathrm{n}$, normal pancreatic tissue; $\mathrm{cp}$, chronic pancreatitis; $-/+$, admixture of positive and negative cells.

a Sometimes referred to as "ectatic, atrophic acini."

1999). At least in our hands, anti-CD95L monoclonal antibody G247-4 is the only reliable clone for immunohistology that is commercially available at present; others like NOK-1, although potently neutralizing in functional assays (Kayagaki et al, 1995), do not stain sufficiently well, even in frozen tissue preparations (Sträter et al, in press). Even G247-4 loses most of its reactivity in paraffin sections due to formalin sensitivity of its epitope (Sträter et al, 1999). Ungefroren et al (1998) correctly state that pancreatic duct epithelium lacks CD95L, but did not give information on CD95L in exocrine and endocrine pancreatic cells.

Coexpression of CD95 and CD95L is thought to be a major prerogative for autocrine suicide in T lymphocytes (Nagata, 1997). Our immunohistologic examination of serial frozen sections strongly suggests that in pancreatic epithelia, expression of CD95 and CD95L is mutually exclusive at the level of cell types and, in chronic pancreatitis, also at the single-cell level in areas where inflammatory changes in expression of CD95 and CD95L are observed. This corresponds to the situation we encountered in other cell types such as colonic epithelium (CD95 $\left.{ }^{+} / \mathrm{CD} 95 \mathrm{~L}^{-}\right)$, Paneth cells $\left(\mathrm{CD}^{-}{ }^{-} \mathrm{CD} \mathrm{CL}^{+}\right)$, other crypt and villus enterocytes of small intestine $\left(\mathrm{CD}^{+} / \mathrm{CD}^{+} \mathrm{L}^{-}\right)$, and plasma cells $\left(\mathrm{CD}^{-}{ }^{-} \mathrm{CD} \mathrm{LL}^{+}\right.$) (Leithäuser et al, 1993; Möller et al, 1993, 1994; Sträter et al, 1997, 1999). Thus, at the phenomenologic level, these cell types seem to be protected against CD95-mediated autocrine death.

Evidently, the induction and surface expression of CD95 is a prerequisite for becoming susceptible to CD95L- mediated signals. We show that in chronic pancreatitis, the CD95 ${ }^{-}$organ neoexpresses CD95 in acinar cells and duct epithelium in a focal manner. These foci of induction correspond to those infiltrated by lymphocytes, mainly $\mathrm{CD} 4^{+} \mathrm{T}$ cells, and early interstitial fibrosis and also to those rich in $\mathrm{HLA}^{-\mathrm{DR}^{+}}$ $\mathrm{CD}_{11 \mathrm{C}^{+}}, \mathrm{CD}^{+/-} \mathrm{S} 100 \mathrm{p}^{+}$interstitial dendritic cells (Grabbe et al, 2000). At the microtopographic level, CD95 induction in exocrine cells is paralleled by HLA-DR induction in these epithelia. Inflammationassociated HLA-DR induction in pancreatic epithelia has been previously described (Bedossa et al, 1990; Pavlovic et al, 1997). This setting strongly suggests an induction of these three molecules by inflammatory cytokines released by the local mononuclear infiltrate. Interestingly, in chronic pancreatitis, these infiltrateassociated changes in expression of CD95, CD95L, and HLA-DR did not occur in islet cells. If CD95mediated apoptosis plays a role in parenchymal damage during pancreatitis, which still has to be proven, our observations would readily explain why islets are frequently unaffected even at advanced stages of this disease.

One major inductor of CD95 in constitutively CD95 cells is the Th1 cytokine INF $\gamma$ (Leithäuser et al, 1993; Möller et al, 1994). IFN $\gamma$ also induces HLA-DR in various constitutively $\mathrm{MHC}$ class $\mathrm{II}^{-}$epithelia (Koretz et al, 1987, 1989). This is also the case in exocrine pancreatic epithelia but not in pancreatic islets (Pavlovic et al, 1997). In our study IFN $\gamma$ tissue levels were significantly higher in chronically inflamed pancreases, suggesting that IFN $\gamma$ is critically involved in this induction. IFN $\gamma$ also up-regulates sensitivity toward CD95mediated cell death (Reyher et al, 1998; Xu et al, 1998). These phenomena were also observed in AsPc1 pancreatic carcinoma cells. In addition, we detected a down-modulation of CD95L at the mRNA and protein level. This again fits very well in the pattern of immunophenotypic changes in chronic pancreatitis described herein. Data on regulatory pathways of CD95L expression are sparse. Sata and Walsh (1999) showed that cyclosporin down-regulates CD95L expression in vascular endothelial cells. Xu et al (1998) state that IFN $\gamma$ and TNF $\alpha$, but not PDGF, EGF, and FGF, up-regulated CD95L in HT29 colon carcinoma cells. However, the bands depicted in this publication do not convincingly show the inducing effect of IFN $\gamma$ and TNF $\alpha$. Furthermore, the authors failed to find CD95L message by RT-PCR, which agrees with our finding of CD95L negativity of HT29 cells. In the same report, Xu et al show a down-modulation of CD95L by IFN $\gamma$ but not by TNF $\alpha$ in U3A, a human fibroblast line lacking STAT-1. STAT-1 transfection into U3A cells was followed by an IFN $\gamma$-mediated up-regulation of CD95L. The question arises whether this transfection restored physiologic levels or led to overexpression of STAT-1. In LS174T human colon carcinoma cells, constitutive CD95L expression was up-regulated by high-dose TNF $\alpha$, whereas IFN $\gamma$ or IL-2 failed to modulate CD95L (Wimmenauer et al, 1999). In critical conclusion, it is too early to generalize the fact that IFN $\gamma$ down-modulates CD95L transcripts and protein in AsPc1 and BxPc3 cells. Nevertheless, IFN $\gamma$ seems to be a good candidate inductor of local changes in the CD95/CD95L status of exocrine pancreatic cells.

We confirm that pancreatic islet cells of normal pancreas are $\mathrm{CD}^{-} 5^{-} \mathrm{CD} 95 \mathrm{~L}^{+}$(Loweth et al, 1998). With regard to the CD95 death receptor system, this is the phenotype of an immunoprivileged site. There is an ongoing discussion on the role that the CD95/ CD95L (Fas/FasL) system plays in immune diabetes (NOD) (Signore et al, 1997; Suarez-Pinzon et al, 1999). Although the wealth of experimental data obtained in mouse systems (Chervonsky et al, 1997; Lau and Stoeckert, 1997) tentatively favors the view that the

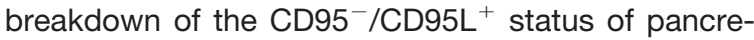
atic islets may be the critical event in NOD mice, open questions and contradictory results remain (Allison and Strasser, 1998; Itoh et al, 1997; Kang et al, 1997; 
A
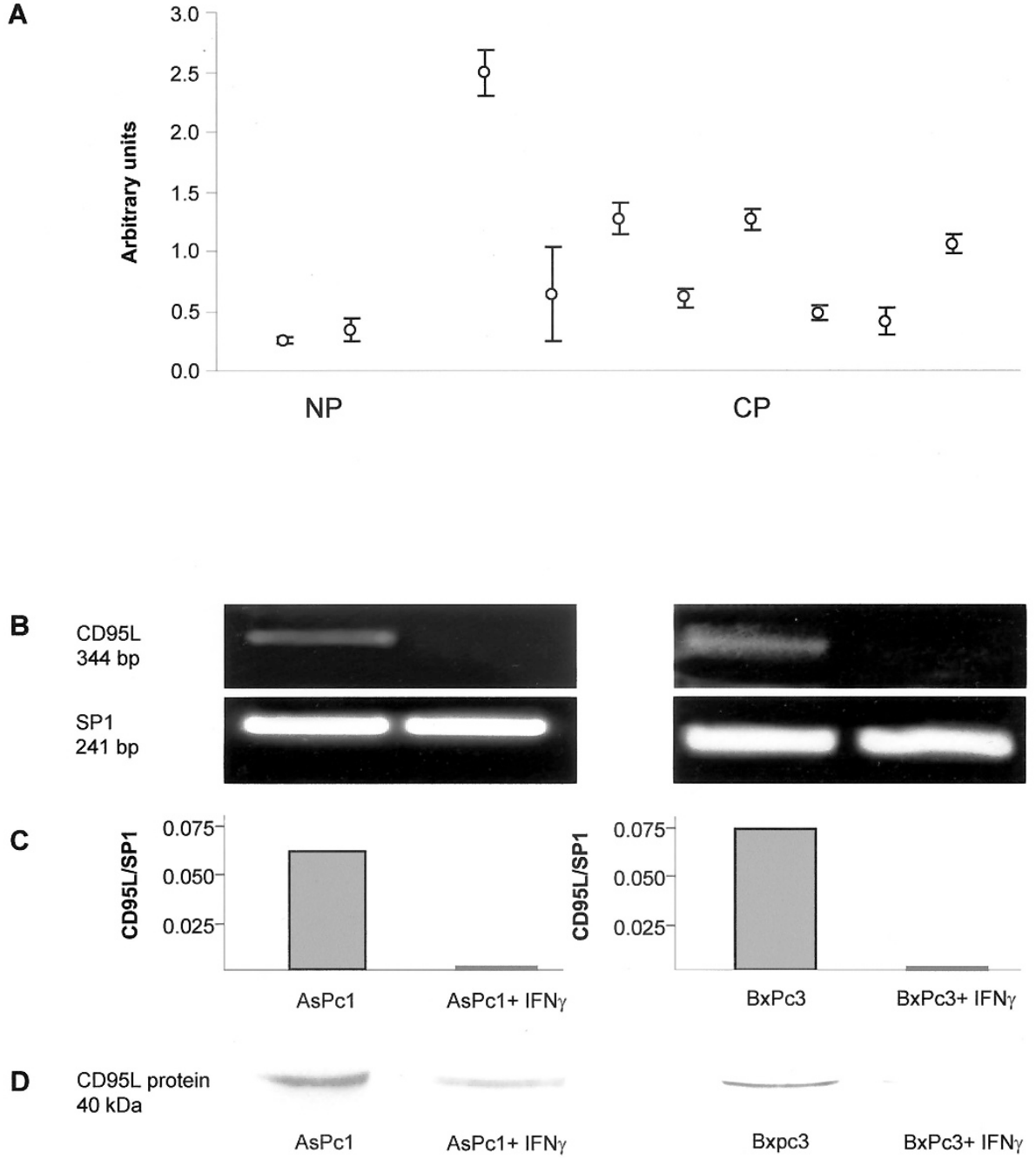

Figure 4.

A, Content of IFN $\gamma$ in protein lysates of specimens of normal pancreas (NP) and chronic pancreatitis $(C P)$, as determined by an enzyme immunoassay. B to D, CD95L transcript and protein expression in AsPc1 and BxPc3 pancreatic carcinoma cells in the absence vs presence of $100 \mathrm{U} / \mathrm{ml} \mathrm{IFN} \gamma$ for 48 hours. B, CD95L and SP1 mRNA detected in an ethidium bromide-stained agarose gel after RT-PCR. C, Ratio profiles of integrated optical densities. D, Immunoblot of Western blotted CD95L protein detected by CD95L monoclonal antibody G247-4 visualized by chemiluminescence

Kim et al, 1999; Thomas et al, 1999). The situation is even less clear in humans. Moriwaki et al (1999) report immunohistochemical findings in biopsy specimens of recent-onset type I diabetic patients. Intact islets were $\mathrm{CD}^{-} 5^{-}$, whereas insulitis was associated with CD95 expression in islet cells, preferentially in $\beta$ cells. Using an antiserum to CD95L, these authors did not detect CD95L in normal and infiltrated islets. We have shown that islets conserve their $\mathrm{CD}^{-} / \mathrm{CD}^{-} 5 \mathrm{~L}^{+}$phenotype even in the vicinity of inflammatory infiltrates of chronic pancreatitis. It is tempting to speculate that, for this reason, islets are often so well conserved in pancreases with advanced atrophy and scar formation in the course of chronic pancreatitis. Therefore, the elusive mechanism(s) initiating NOD by breakdown of the $\mathrm{CD}^{-} 5^{-} / \mathrm{CD} \mathrm{L}^{+}$status of islets might be different from those operative in chronic pancreatitis. The reported switch of the $\mathrm{CD}^{-} 5^{-} / \mathrm{CD} 5 \mathrm{~L}^{+} / \mathrm{HLA}^{-D R^{-}}$protector status of pancreatic acinar cells to $\mathrm{CD}^{-} 5^{+} /$ $\mathrm{CD} 5 \mathrm{~L}^{-} / \mathrm{HLA}-\mathrm{DR}^{+}$, probably triggered by $\mathrm{IFN} \gamma$, may confer susceptibility to $\mathrm{CD} 4^{+} \mathrm{Th} 1$-mediated cytotoxic- ity (Ju et al, 1994; Lynch et al, 1995) and hence be a crucial step in parenchymal destruction during chronic pancreatitis.

\section{Materials and Methods}

\section{Pancreatic Tissues}

Eighteen patients, whose informed consent was obtained before surgery, were chosen for this study. Thirteen of these patients underwent partial pancreatectomy for chronic pancreatitis, eight of them had alcoholic pancreatitis, three had chronic non-alcoholic pancreatitis connected with pancreas divisum, one developed a cyst after initial surgery, and one had cryptogenic chronic pancreatitis. Five patients underwent partial pancreatectomy for pancreas divisum. The specimens of these five patients were histopathologically diagnosed as normal pancreas and were included in the study as normal controls. All pancreatectomy specimens were immediately transferred to 
the laboratory where representative tissue samples were snap frozen in liquid nitrogen and kept there until further processing, ie, RNA and protein isolation by methods described below. Other parts of the quickfrozen tissues were stored at $-80^{\circ} \mathrm{C}$ to be later used for frozen section immunohistochemistry.

\section{Cell Culture}

AsPc1 and BxPc3, two human pancreatic carcinoma cell lines, and HT29, a human colon carcinoma cell line, were purchased from American Type Culture Collection (Rockville, Maryland), kept in a humidified incubator at $37^{\circ} \mathrm{C}$ in $5 \% \mathrm{CO}_{2}$ atmosphere and cultured in Iscove's modified Dulbecco's medium (IMDM) (Biochrom, Berlin, Germany)/Roswell Park Memorial Institute medium (RPMI) (Life Technologies, Paisley, Scotland) supplemented with 10\% FCS (PAA, Linz, Austria), $5 \mathrm{~mm}$ glutamine, $100 \mathrm{U} / \mathrm{ml}$ penicillin, and 100 $\mu \mathrm{g} / \mathrm{ml}$ streptomycin (BioWhittaker, Veviers, Belgium). To examine CD95L expression under IFN $\gamma$-stimulated conditions, cells were seeded in $\varnothing 25 \mathrm{~mm}^{2}$ culture plates (Nalge Nunc, Naperville, Illinois), allowed to adhere for 24 hours, then treated with IFN $\gamma$ (Boehringer Mannheim, Mannheim, Germany) for another 48 hours. Cells were washed once with PBS w/o (Life Technologies) and harvested with trypsin (500 mg/l)/ EDTA (200 mg/l) 1:250 (BioWhittaker).

\section{mRNA Preparation and RT-PCR}

RNA from tissue samples was prepared as described by Chomczynski and Sacchi (1987), then digested with RNase-free DNase I (Boehringer Mannheim). RNA from cell lines was extracted with TriZol Reagent (Life Technologies) according to the manufacturer's instructions, reversely transcribed using Superscript Reverse Transcriptase (Life Technologies), random hexamer primer, and addition of a RNase-inhibitor following the manufacturer's protocol. Semiquantitative triplex PCR was performed on cDNA using the Taq PCR Core Kit (Qiagen, Hilden, Germany) and the following sense and antisense primers: human transcription factor SP1: 5'-ACT ACC AGT GGA TCA TCA GGG-3 and 5'-CTG ACA ATG GTG CTG CTT GGA-3'; Fas Ligand: 5'-GGA TTG GGC CTG GGG ATG TाT CA-3' and 5'-TTG TGG CTC AGG GGC AGG TTG TTG-3. The length of amplicons are 241 bp and $344 \mathrm{bp}$. Thermocycling included the following steps: denaturation at $95^{\circ} \mathrm{C}$ for 5 minutes, 25 cycles: $95^{\circ} \mathrm{C}$ for 1 minute, $56^{\circ} \mathrm{C}$ for 1 minute, $72^{\circ} \mathrm{C}$ for 1 minute, and prolongation for 10 minutes at $72^{\circ} \mathrm{C}$. Primers were used in a final concentration of $0.5 \mu \mathrm{M}$ each, dNTPs at $10 \mu \mathrm{m}, 2.5 \mathrm{U}$ of Taq DNA polymerase in a total of $50 \mu \mathrm{l}, 10 \times$ buffer and $5 \times \mathrm{Q}$-Solution according to the instructions. Omitting RT reaction resulted in no detectable PCR products. Electrophoretically separated PCRproducts were ethidium-bromide stained and the fluorescence image of the amplicons were analyzed by ImageMaster VDS (Pharmacia Biotec, San Francisco, California). The ratio of the background corrected integrated optical densities of the DNA bands related to SP1 expression were calculated. RNA extraction and further processing was successful in 12 of 18 pancreases, but the RNA from 6 pancreases was degraded, probably due to endogenous RNase.

\section{Immunohistochemisty}

Serial, 2- $\mu \mathrm{m}$ thick cryosections were immediately fixed in ice-cold acetone for 10 minutes, air-dried and incubated for 1 hour with the following mouse antihuman monoclonal antibodies in appropriate dilutions: CD95L clone G 247-4, IgG1 isotype (PharMingen, San Diego, California), CD95 (anti-APO-1), IgG1 isotype, (DAKO, Copenhagen, Denmark), CD3(Leu4), IgG1 isotype (Becton Dickinson, Mountain View, California), CD4 (OKT4), IgG2a isotype, and CD11c(BU15), IgG1 isotype (Immunotech, Marseille, France). Anti-HLA-DR clone 1B5, IgG1 isotype, was generously contributed by Gerhard Moldenhauer (Deutsches Krebsforschungszentrum, Heidelberg, Germany). A purified rabbit antiserum to bovine S100p reactive with human $\mathrm{S100p}$ (DAKO) was also used. Bound primary antibody was detected via goat antimouse or antirabbit immunoglobulins conjugated to peroxidase-labeled dextran polymer in Tris-HCL buffer containing carrier protein (EnVision; DAKO). 3-amino-9ethyl-carbazole (Sigma, St. Louis, Missouri) was used for substrate. Counterstain was performed with hemalum. Controls were performed by omitting the first-step antibody and yielded negative results, with the exception of stained granulocytes inconsistently present. Granulocyte staining was due to endogenous peroxidase that was not blocked for the sake of unimpaired antigenicity of the tissue.

\section{Immunoblotting of CD95L Protein}

Tissue samples were picked up in ice-cold lysis buffer (50 mmol/l Tris-HCl [pH 7.4], $150 \mathrm{mmol} / \mathrm{l} \mathrm{NaCl}, 10$ $\mathrm{mmol} / /$ EDTA [pH 8.0], $1 \%$ nonidet P-40, $10 \mu \mathrm{M}$ PMSF, $1 \%$ sodium vanadate, 1 tablet of complete [Boehringer Mannheim]), a protease-inhibitor cocktail, then homogenized, sonified, and incubated for 1 hour at $4^{\circ} \mathrm{C}$. Cells harvested as described above were lysed in boiling lysis buffer for 3 minutes. After centrifugation supernatant was removed and protein concentration determined using Bradford reagent (Bio-Rad, Munich, Germany). One hundred micrograms of every total protein lysate was separated on a $10 \%$ to $20 \%$ Tricine precast gel (Novex, San Diego, California) and transferred to a polyvinylidene difluoride membrane. Membranes were incubated with antihuman CD95L, clone G247-4, for 1 hour after blocking in PBS containing 5\% non-fat dried milk at room temperature. Membranes were washed three times with PBS $/ 0,02 \%$ Tween 20 , then incubated with sheep antimouse biotinylated immunoglobulins $(1: 5,000)$ and streptavidin (1:5,000; Amersham, Arlington Heights, Illinois). Protein lysates of AsPc1 and HT29 cells served as positive and negative control, respectively. After another three washes, the blots were developed by enhanced chemiluminescence using the ECL system (Amersham). 


\section{Human IFN $\gamma$ Sandwich EIA}

To determine tissue concentrations of IFN $\gamma$, we prepared protein lysates extracted from snap-frozen tissue specimens of two normal pancreases and eight pancreases with chronic pancreatitis. We applied a commercial EIA kit containing a recombinant human IFN $\gamma$ preparation as the standard (CYTELISA; CYTimmune Sciences, College Park, Maryland). For antigen capture, $100 \mu$ l of each protein lysate, together with a dilution series of the standard, were dispensed in triplicate in 96-well microtiter plates precoated with murine monoclonal antibodies against human IFN $\gamma$. Simultaneously, $25 \mu$ of IFN $\gamma$ specific rabbit antihuman polyclonal antibody per well were added for detection. Plates were sealed and incubated for 3 hours at room temperature. After repeated washing, $50 \mu \mathrm{l}$ of goat antirabbit conjugated alkaline phosphatase were added, plates were resealed and incubated for 45 minutes at room temperature and then washed again. A two-step color-generating system was used according to the manufacturer's instructions. Briefly, the system is based first on dephosphorylation of NADH to NAD by alkaline phosphatase, and then by NADH serving as a cofactor activating a cycling redox reaction maintained by alcohol dehydrogenase and diaphorase. This reaction leads to the formation of the red product formazan, which absorbs light at $492 \mathrm{~nm}$. Two hundred microliters of the color reagent were dispensed in each well. The light absorption was measured and calibrated against the standard with a MRX microplate reader (Dynatech Laboratories, Chantilly, Virginia). All wells were measured in triplicate. Results were analyzed using the Revelation software (Dynatech) and were given in arbitrary units as means with standard deviations. The Wilcoxon test was applied for statistical comparison of values of normal pancreas and chronic pancreatitis.

\section{Acknowledgements}

The authors thank Silke Dauser and Anke Gruber for excellent technical assistance.

\section{References}

Allison $\mathrm{J}$ and Strasser A (1998). Mechanisms of $\beta$ cell death in diabetes: A minor role for CD95. Proc Natl Acad Sci USA 95:13818-13822

Bedossa P, Bacci J, Lemaigre G, and Martim E (1990). Lymphocyte subsets and HLA-DR expression in normal pancreas and chronic pancreatitis. Pancreas 5:415-420

Bernstorff W, Spanjaard RA, Chan AK, Lockhart DC, Sadanaga N, Wood I, Peiper M, Goedegebuure P, and Eberlein TJ (1999). Pancreatic cancer cell lines can evade immune surveillance via nonfunctional Fas (APO-1/CD95) receptors and aberrant expression of functional Fas ligand. Surgery 125:73-84

Bockman DE (1997). Morphology of the exocrine pancreas related to pancreatitis. Microsc Res Tech 37:509-519
Chervonsky AV, Wang Y, Wong FS, Visintin I, Flavell RA, Janeway CA, and Matis LA (1997). The role of Fas in autoimmune diabetes. Cell 89:17-24

Chomczynski P and Sacchi N (1987). Single-step method of RNA isolation by acid guanidinium thiocyanate-phenolchloroform extraction. Anal Biochem 162:156-159

Dhein J, Walczak H, Bäumler C, Debatin KM, and Krammer PH (1995). Autocrine T-cell suicide mediated by APO-1. Nature 373:438-441

Ectors N, Maillet B, Aerts R, Geboes K, Donner A, Borchard F, Lankisch P, Stolte M, Lüttges J, Kremer B, and Klöppel G (1997). Non-alcoholic duct destuctive chronic pancreatitis. Gut 41:263-268

Grabbe S, Kämpgen E, and Schuler G (2000). Dendritic cells: Multi-lineal and multi-functional. Immunol Today 21:431-433

Hunger RE, Mueller C, Z'Graggen K, Friess H, and Büchler MW (1997). Cytotoxic cells are activated in cellular infiltrates of alcoholic chronic pancreatitis. Gastroenterology 112: $1656-1663$

Itoh N, Imagawa A, Hanafusa T, Waguri M, Yamamoto K, Iwashi $\mathrm{H}$, Moriwaki M, Nakajima H, Miyagawa J, Namba M, Makino S, Nagata S, Kono N, and Matsuzawa Y (1997). Requirement of Fas for the development of autoimmune diabetes in nonobese diabetic mice. J Exp Med 4:613-618

Jalleh RP, Gilbertson JA, Williamson RC, Slater SD, and Foster DS (1993). Expression of major histocompatibility antigens in human chronic pancreatitis. Gut 34:1452-1457

Ju ST, Cui H, Panka DJ, Ettinger R, and Marshak-Rothstein A (1994). Participation of target Fas protein in apoptosis pathway induced by $\mathrm{CD} 4^{+} \mathrm{TH} 1$ and $\mathrm{CD} 8^{+}$cytotoxic T cells. Proc Natl Acad Sci USA 91:4185-4189

Kang SM, Schneider DB, Lin Z, Hanahan D, Dichek DA, Stock PG, and Baekkeskov S (1997). Fas ligand expression in islets of Langerhans does not confer immune privilege and instead targets them for rapid destruction. Nat Med 3:738743

Kayagaki $\mathrm{N}$ and Kawasaki A, Ebata $\mathrm{T}$, Ohmoto $\mathrm{H}$, Ikeda $\mathrm{S}$, Inoue S, Yoshino K, Okumura K, and Yagita H (1995). Metalloproteinase-mediated release of human Fas ligand. $J$ Exp Med 182:1777-1783

Kim YH, Kim S, Kim KA, Yagita H, Kayagaki N, Kim KW, and Lee MS (1999). Apoptosis of pancreatic $\beta$-cells detected in accelerated diabetes of NOD mice: No role of Fas-Fas ligand interaction in autoimmune diabetes. Eur J Immunol 29:455465

Klöppel G and Maillet B (1993). Pathology of acute and chronic pancreatitis. Pancreas 8:659-670

Koretz K, Moldenhauer G, Majdic O, and Möller P (1989). Correlation of HLA-D/li antigen expression in breast carcinoma with local lymphohistiocytic infiltration reveals considerable dysregulation in a subset of tumors. Int $\mathrm{J}$ Cancer 44:816-822

Koretz K, Momburg F, Otto HF, and Möller P (1987). Sequential induction of MHC antigens on autochthonous cells of the ileum affected by Crohn's disease. Am J Pathol 129:493-502

Lau TL and Stoeckert CJ (1997). FasL: Too much of a good thing? Nat Med 3:727-728

Lee SH, Shin MS, Park WS, Kim SU, Dong SM, Lee HK, Park JY, Oh RR, Jang JJ, Lee JY, and Yoo NJ (1999). Immuno- 
histochemical analysis of Fas ligand expression in normal human tissues. APMIS 107:1013-1019

Leithäuser F, Dhein J, Mechtersheimer G, Koretz K, Brüderlein S, Henne C, Schmidt A, Debatin KM, Krammer PH, and Möller P (1993). Constitutive and induced expression of APO-1: A new member of the nerve growth factor/tumor necrosis factor superfamily, in normal and neoplastic cells. Lab Invest 69:415-429

Loweth AC, Williams GT, James RFL, Scarpello JHB, and Morgan NG (1998). Human islets of Langerhans express Fas ligand and undergo apoptosis in response to interleukin- $1 \beta$ and Fas ligation. Diabetes 47:727-732

Lynch DH, Ramsdell F, and Alderson MR (1995). Fas and FasL in the homeostatic regulation of immune responses. Immunol Today 16:569-574

Moldenhauer G, Henne C, Karhausen J, and Möller P (1999). Surface-expressed invariant chain(CD74) is required for internalization of human leucocyte antigen-DR molecules to early endosomal compartments. Immunology 96:473-484

Möller P, Henne C, Leithäuser F, Eichelmann A, Schmidt A, Brüderlein S, Dhein J, and Krammer PH (1993). Coregulation of the APO-1 antigen with intercellular adhesion molecule1(CD54) in tonsillar B cells and coordinate expression in follicular center $B$ cells and in follicle center and mediastinal B-cell lymphomas. Blood 81:2067-2075

Möller P, Koretz K, Leithäuser F, Brüderlein S, Henne C, Quentmeier A, and Krammer PH (1994). Expression of APO1(CD95), a member of the NGF/TNF receptor superfamily, in normal and neoplastic colon epithelium. Int J Cancer 57:371377

Möller P, Walczak H, Riedl S, Sträter J, and Krammer PH (1996). Paneth cells express high levels of CD95 ligand transcripts. Am J Pathol 149:9-13

Moriwaki M, Itoh N, Miyagawa J, Yamamoto K, Imagawa A, Yamagata K, Iwahashi H, Nakajima H, Namba N, Nagata S, Hanafusa T, and Matsuzawa Y (1999). Fas and Fas ligand expression in inflamed islets in pancreas sections of patients with recent-onset Type I diabetes mellitus. Diabetologia 42:1332-1340

Nagata S (1997). Apoptosis by death factor. Cell 88:355-365

O'Connell J, Sullivan GCO, Collins JK, and Shanahan F (1996). The Fas counterattack: Fas-mediated T cell killing by colon cancer cells expressing Fas ligand. J Exp Med 184: 1075-1082

Pavlovic D, van de Winkel M, van der Auwera B, Chen MC, Schuit F, Bouwens L, and Pipeleers D (1997). Effect of interferon- $\gamma$ and glucose on major histocompatibility complex class I and class II expression by pancreatic $\beta$ - and non- $\beta$-cells. J Clin Endocrinol Metab 82:2329-2336

Peter ME and Krammer PH (1998). Mechanisms of CD95 (APO-1/Fas)-mediated apoptosis. Curr Opin Immunol 10:545 551

Reyher U, Sträter J, Kittstein W, Gschwendt M, Krammer PH, and Möller P (1998). Colon carcinoma cells use different mechanisms to escape CD95-mediated apoptosis. Cancer Res 58:526-534
Sarles H (1991). Definitions and classifications of pancreatitis. Pancreas 6:470-474

Sata M and Walsh K (1999). Cyclosporine downregulates Fas ligand expression on vascular endothelial cells: Implication for accelerated vasculopathy by immunosuppressive therapy. Biochem Biophys Res Commun 263:430-432

Saurer L, Reber P, Schaffner T, Büchler MW, Buri C, Kappeler A, Walz A, Friess H, and Mueller C (2000). Differential expression of chemokines in normal pancreas and in chronic pancreatitis. Gastroenterology 118:356-367

Signore A, Annovazzi A, Procaccini E, Beales PE, Spencer J, Testi R, and Ruberti G (1997). CD95 and CD95-ligand expression in endocrine pancreas of NOD, NOR and BALB/c mice. Diabetologia 40:1476-1479

Sträter J, Mariani SM, Walczak H, Rücker FG, Leithäuser F, Krammer PH, and Möller P (1999). CD95 ligand (CD95L) in normal human lymphoid tissues. Am J Pathol 154:193-201

Sträter J, Walzcak H, Hasel C, Melzmo J, Leithäuser F, and Möller P (2001). CD95 ligand (CD95L) immunochemistry: A critical study of 12 antibodies. Cell Death Differ (in press).

Sträter J, Wellisch I, Riedl S, Walczak H, Koretz K, Tandara A, Krammer PH, and Möller P (1997). CD95(APO-1/Fas)mediated apoptosis in colon epithelial cells: A possible role in ulcerative colitis. Gastroenterology 113:160-167

Suarez-Pinzon W, Sorensen O, Bleakley RC, Elliott JF, Rajotte RV, and Rabinovitch A (1999). $\beta$-cell destruction in NOD mice correlates with Fas(CD95) expression on $\beta$-cells and proinflammatory cytokine expression in islets. Diabetes 48 : 21-28

Takahashi T, Tanaka M, Inazawa J, Abe T, Suda T, and Nagata S (1994). Human Fas ligand: Gene structure, chromosomal location and species specificity. Int Immunol 10: 1567-1574

Tanaka M, Suda T, Takahashi T, and Nagata S (1995). Expression of the functional soluble form of human Fas ligand in activated lymphocytes. EMBO J 14:1129-1135

Thomas HE, Darwiche R, Corbett JA, and Kay TWH (1999). Evidence that $\beta$ cell death in the nonobese diabetic mouse is Fas independent. J Immunol 163:1562-1569

Ungefroren H, Voss M, Jansen M, Roeder C, Henne-Bruns D, Kremer B, and Kalthoff H (1998). Human pancreatic adenocarcinomas express Fas and Fas ligand yet are resistant to Fas-mediated apoptosis. Cancer Res 58:1741-1749

Wimmenauer S, Steiert A, Wolff-Vorbeck G, Xing B, Baier PK, Ruckauer KD, Kirste G, and von Kleist S (1999). Influence of cytokines on the expression of fas ligand and CD44 splice variants in colon carcinoma cells. Tumour Biol 20:294-303

Xerri L, Devilard E, Hassoun J, Mawas C, and Birg F (1997). Fas ligand is not only expressed in immune privileged human organs but is also coexpressed with Fas in various epithelial tissues. Mol Pathol 50:87-91

Xu X, Fu XY, Plate J, and Chong ASF (1998). IFN- $\gamma$ induces cell growth inhibition by Fas-mediated apoptosis: Requirement of STAT1 protein for up-regulation of Fas and FasL expression. Cancer Res 58:2832-2837 